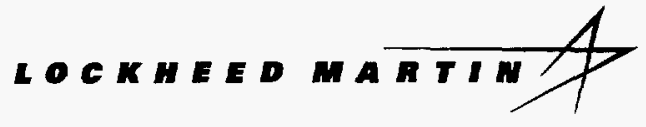

ENVIRONMENTAL RESTORATION PROGRAM

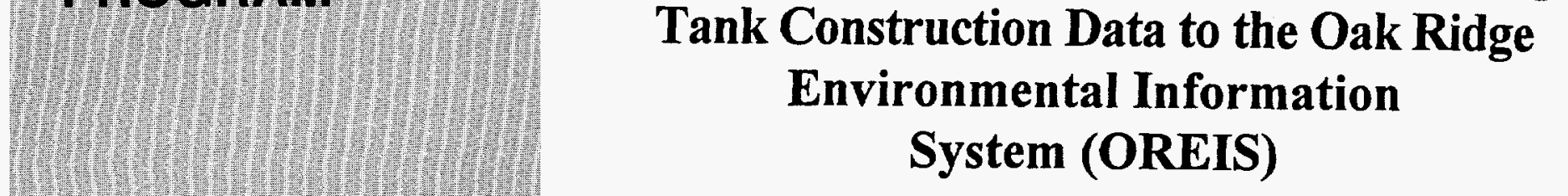

\title{
Technical Specification for Transferring Tank Construction Data to the Oak Ridge System (OREIS)
}

\author{
RECEIVED \\ JUN 281996 \\ OSTI
}

\section{DISCLAIMER}

This report was prepared as an account of work sponsored by an agency of the United States Government. Neither the United States Government nor any agency thereof, nor any of their employees, makes any warranty, express or implied, or assumes any legal liability or responsibility for the accuracy, completeness, or usefulness of any information, apparatus, product, or process disclosed, or represents that its use would not infringe privately owned rights. Reference herein to any specific commercial product, process, or service by trade name, trademark, manufacturer, or otherwise does not necessarily constitute or imply its endorsement, recommendation, or favoring by the United States Government or any agency thereof. The views and opinions of authors expressed herein do not necessarily state or reflect those of the United States Government or any agency thereof.

This document has been approved by the K-25 Site Technical Information Office for release to the public. Date: $6 / 13 / 96$

DISTRIBUTION OF THIS DOCUMENT IS UNLIMITED

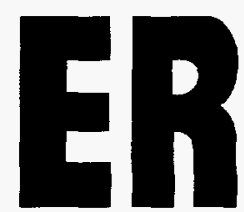


This report has been reproduced directly from the best available copy.

Available to DOE and DOE contractors from the Office of Scientific and

Technical Information, P.O. Box 62, Oak Ridge, TN 37831; prices available from 423-576-8401 (fax 423-576-2865).

Available to the public from the National Technical Information Service,

U.S. Department of Commerce, 5285 Port Royal Rd., Springfield, VA. 22161 


\section{DISCLAIMER}

Portions of this document may be illegible in electronic image products. Images are produced from the best available original document. 


\title{
Technical Specification for Transferring Tank Construction Data to the Oak Ridge Environmental Information System (OREIS)
}

\author{
Environmental Restoration Division \\ P. O. Box 2003 \\ Oak Ridge, Tennessee 37831-7298
}

Date Issued-June 1996

Prepared by the

Oak Ridge Environmental Information System

(OREIS) Program

Prepared for

U.S. Department of Energy

Office of Environmental Management

under budget and reporting code EW 20

LOCKHEED MARTIN ENERGY SYSTEMS, INC.

managing the

Environmental Management Activities at the

Oak Ridge K-25 Site Paducah Gaseous Diffusion Plant

Oak Ridge Y-12 Plant Portsmouth Gaseous Diffusion Plant

Oak Ridge National Laboratory

under contract DE-AC05-84OR21400

for the

U.S. Department of Energy 


\section{APPROVAL}

\section{Technical Specification for Transferring Tank Construction Data to the Oak Ridge \\ Environmental Information \\ System (OREIS) \\ (ES/ER/TM-189)}

Approved by

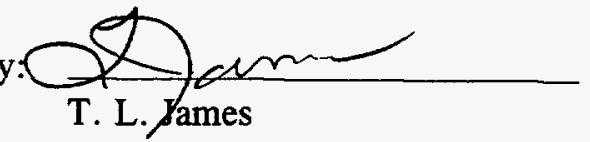

Date: $5 / 10 / 96$

OREIS Data Base Team Leader

Approved by:

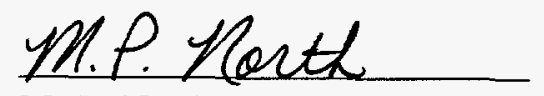

M. P. North

Date: $5 / 10 / 96$

OREIS Data Modeler/Tank Team Facilitator

Approved by:

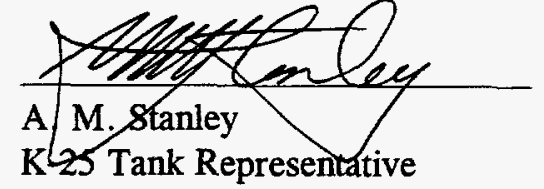

Approved by:

m\& whithos

M. L. Whitehead

LMES Inactive Tanks Fagility Manager

Approved by:

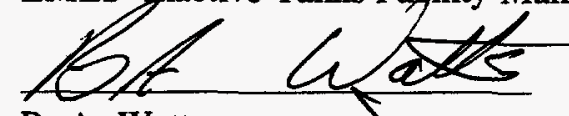

B A. Watts

OREIS Program Manage

Approved by:

Date:

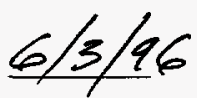

Date: $5 / 10 / 96$ 


\section{PREFACE}

The purpose of this technical specification report is to address the consolidated environmental data requirements of the Federal Facility Agreement (FFA) and the Tennessee Oversight Agreement (TOA) and to document the technical specifications for transmitting tank construction data to the Oak Ridge Environmental Information System (OREIS). This work was performed under Work Breakdown Structure Number 1.4.12.2.3.04.04.01 (Activity Data Sheet 8304). 


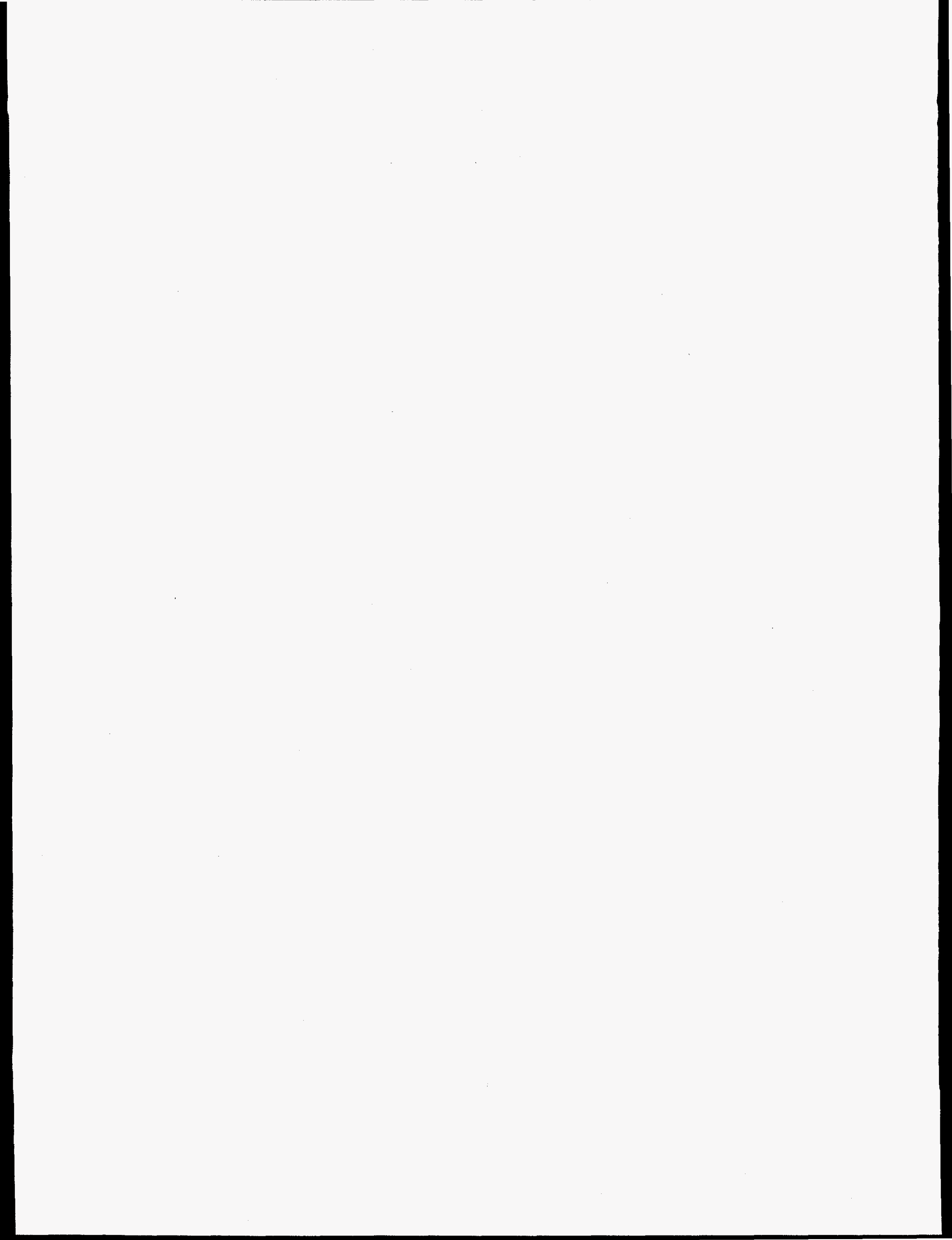




\section{ACKNOWLEDGMENTS}

B. A. Watts, an employee of Environmental Restoration, Lockheed Martin Energy Systems, Inc. (LMES), is Program Manager of the Oak Ridge Environmental Information System (OREIS). OREIS Team Leaders are P. J. Pace, T. L. James, M. L. Land, J. K. Thomas, and E. P. Tinnel. E. P. Tinnel is a member of the Computational Physics and Engineering Division (CPED), Oak Ridge National Laboratory (ORNL); P. J. Pace and T. L. James are University of Tennessee (UT) subcontractors with CPED. M. L. Land and J. K. Thomas are members of the Health Sciences Research Division (HSRD), ORNL.

M. P. North, lead author of this document and facilitator for the Tanks Technical Specifications Team, is a member of Data Systems Research and Development (DSRD), LMES.

The author acknowledges the contributions of the members of the Tank Specifications Team who were instrumental in developing the specifications presented in this document. Team members and their affiliations include: G. W. Thompson, a former member of Environmental Restoration Division, LMER; M. L. Whitehead, a member of Environmental Restoration Division, LMES; A. M. Stanley, a member of Health Sciences Research Division, LMER; T. L. James, a UT subcontractor with CPED, LMER; and B. C. Zygmunt, a member of CPED, LMER. 



\section{CONTENTS}

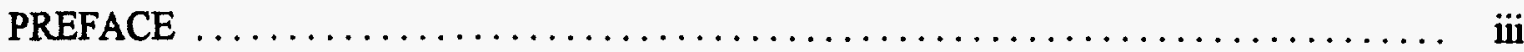

ACKNOWLEDGMENTS $\ldots \ldots \ldots \ldots \ldots \ldots \ldots \ldots \ldots \ldots \ldots \ldots \ldots \ldots \ldots \ldots \ldots$

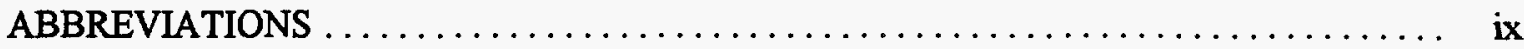

EXECUTIVE SUMMARY $\ldots \ldots \ldots \ldots \ldots \ldots \ldots \ldots \ldots \ldots \ldots \ldots \ldots \ldots \ldots \ldots \ldots \ldots \ldots \ldots$

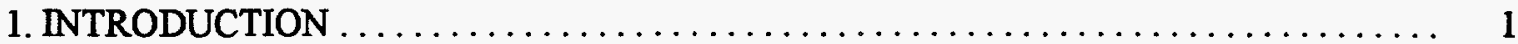

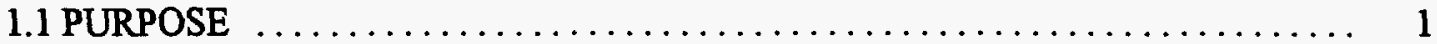

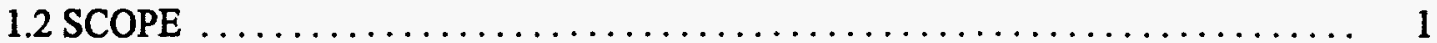

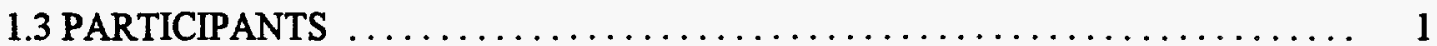

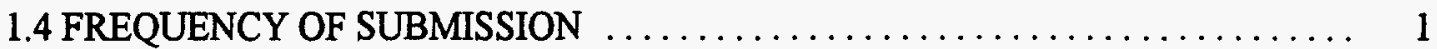

1.5 OREIS DATA MODEL $\ldots \ldots \ldots \ldots \ldots \ldots \ldots \ldots \ldots \ldots \ldots \ldots \ldots \ldots$

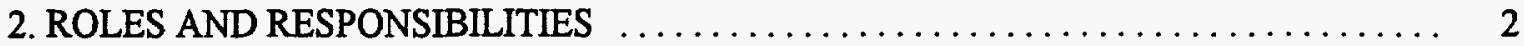

2.1 ENVIRONMENTAL RESTORATION ORGANIZATION $\ldots \ldots \ldots \ldots \ldots \ldots \ldots, 2$

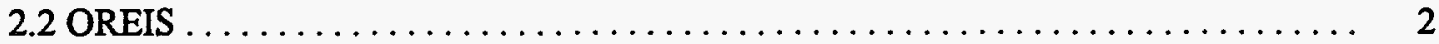

3. LOGICAL FILE LAYOUT AND BUSINESS RULES $\ldots \ldots \ldots \ldots \ldots \ldots \ldots \ldots \ldots \ldots$

3.1 TANK CONSTRUCTION DATA $\ldots \ldots \ldots \ldots \ldots \ldots \ldots \ldots \ldots \ldots \ldots \ldots \ldots \ldots \ldots \ldots$

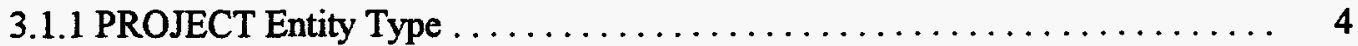

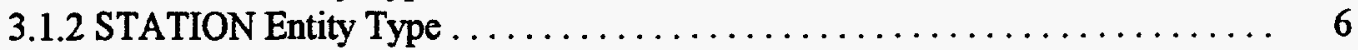

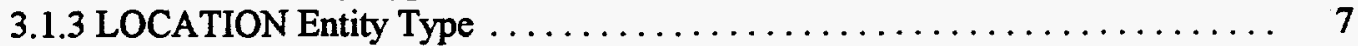

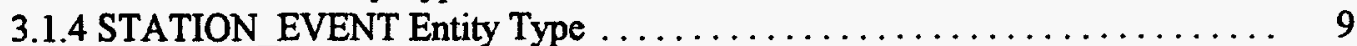

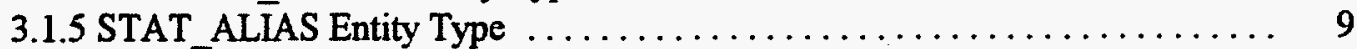

3.1.6 PROJECT STATION_EVENT Entity Type $\ldots \ldots \ldots \ldots \ldots \ldots \ldots \ldots \ldots . \ldots \ldots$

3.1.7 TANK Entity Type ................................. 10

3.1.8 TANK MEDIA TYPE Entity Type $\ldots \ldots \ldots \ldots \ldots \ldots \ldots \ldots \ldots \ldots \ldots \ldots$

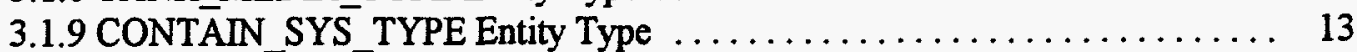

3.1.10 REFERENCE_SOURCE Entity Type $\ldots \ldots \ldots \ldots \ldots \ldots \ldots \ldots \ldots \ldots \ldots$

4. CHANGES TO OREIS DATA MODEL $\ldots \ldots \ldots \ldots \ldots \ldots \ldots \ldots \ldots \ldots \ldots \ldots \ldots \ldots \ldots \ldots \ldots \ldots$

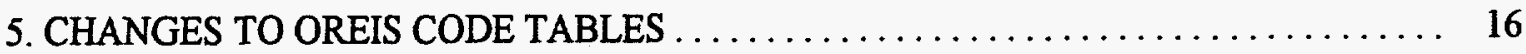

6. VALID VALUES FOR OREIS CODE_TYPES $\ldots \ldots \ldots \ldots \ldots \ldots \ldots \ldots \ldots \ldots \ldots$

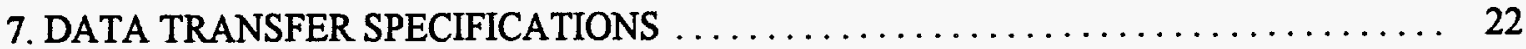

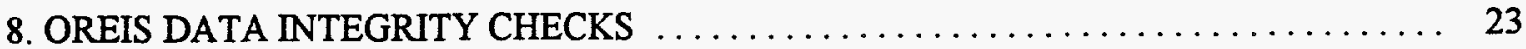

9. REQUESTING CHANGES TO TANK CONSTRUCTION
DATA IN OREIS $\ldots \ldots \ldots \ldots \ldots \ldots \ldots \ldots \ldots \ldots \ldots \ldots \ldots \ldots \ldots \ldots \ldots \ldots \ldots \ldots \ldots \ldots$

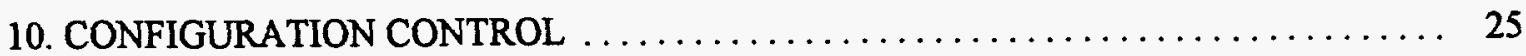


Appendix. OREIS ENTITY RELATIONSHIP DIAGRAM

A-1 


\section{ABBREVIATIONS}

C

CPED

CWA

DOE

EPA

ER

FCAP

FFA

HSRD

LMES

M

$\mathrm{M} \& \mathrm{O}$

msl

NPDES

OREIS

ORNL

ORR

PAD

PORTS

$\mathrm{R}$

RTL

SWMU

TDEC

TOA

UT

conditional

Computational Physics and Engineering Division

Clean Water Act

U.S. Department of Energy

Environmental Protection Agency

Environmental Restoration

Filled Coal Ash Pond

Federal Facility Agreement

Health Sciences Research Division

Lockheed Martin Energy Systems, Inc.

mandatory

Maintenance and Operations

mean sea level

National Pollutant Discharge Elimination System

Oak Ridge Environmental Information System

Oak Ridge National Laboratory

Oak Ridge Reservation

Paducah Gaseous Diffusion Plant

Portsmouth Gaseous Diffusion Plant

recommended

ready-to-load

Solid Waste Management Unit

Tennessee Department of Environment and Conservation

Tennessee Oversight Agreement

University of Tennessee 


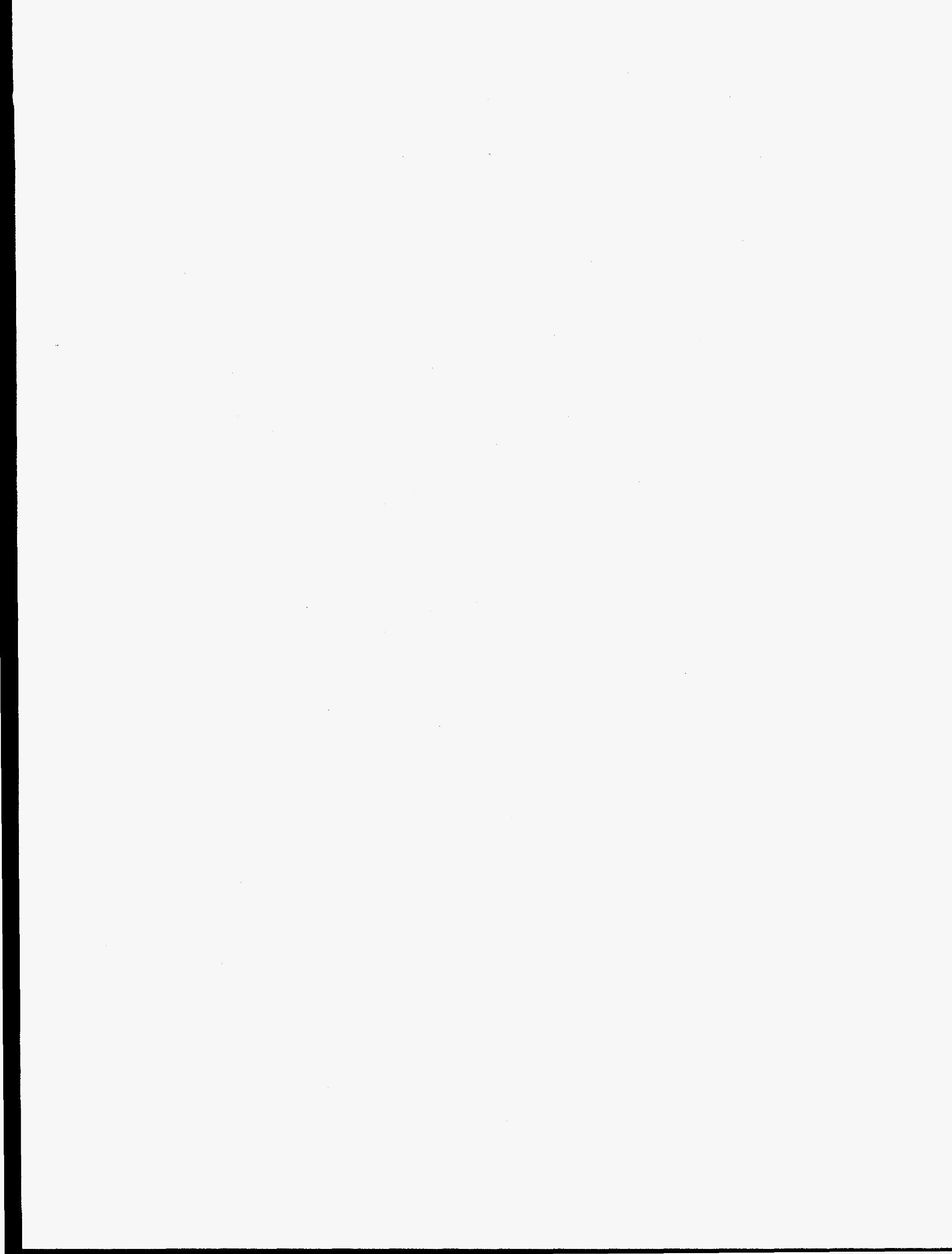




\section{EXECUTIVE SUMMARY}

In February 1996, a team was formed to develop, document, and implement technical specifications for transmitting tank construction data to the Oak Ridge Environmental Information System (OREIS). This document describes the requirements, responsibilities, criteria, and format for transmitting tank construction data to OREIS as determined by the Tank Technical Specification Team. The approach used to transmit these data is documented in ERWM/ER-P2701, Transmitting Data to the Oak Ridge Environmental Information System. 


\section{INTRODUCTION}

\subsection{PURPOSE}

The primary goal of this technical specification is to meet the consolidated environmental data requirements defined by the Federal Facility Agreement (FFA) and the Tennessee Oversight Agreement (TOA) as they pertain to tank construction data maintained in Oak Ridge, Tennessee, by the U.S. Department of Energy's (DOE) Maintenance and Operations (M\&O) contractor Lockheed Martin Energy Systems, Inc. (LMES), and prime contractors to the Department of Energy (DOE).

This technical specification describes the organizational responsibilities for loading tank construction data into OREIS, describes the logical and physical data transfer files, addresses business rules and submission nules, addresses configuration control of this technical specification, and addresses required changes to the current OREIS data base structure based on site requirements.

\subsection{SCOPE}

This technical specification addresses the tank construction data maintained by the $Y-12, K-25$, and ORNL sites that will be sent to OREIS. The initial submission of data will include only inactive Environmental Restoration tanks as specified by the FFA.

\subsection{PARTICIPANTS}

The team consisted of site tank representatives and OREIS technical staff. The initial activities required tank representatives to determine the availability of data for loading into OREIS and to alter data management activities as required to conform to a common data transfer specification. Follow-on activities required computing personnel to modify, test, and implement application systems to transfer the data via the technical specification.

\subsection{FREQUENCY OF SUBMISSION}

When fully implemented, tank construction data will be sent to OREIS for the inactive Environmental Restoration FFA tanks which pertain to the gunite monitoring tank data and the Old Hydrofracture Facility monitoring tank data. Any new tank construction data will be sent to OREIS prior to or with any associated tank measurements data.

\subsection{OREIS DATA MODEL}

Reference the latest revision of the Data Dictionary for the Oak Ridge Environmental Information System, ES/ER/TM-116 for a definition of the measurement data base structures, descriptions of the data base tables, and listings of valid values for codes, parameters, and methods.

The appendix contains the OREIS Entity Relationship Diagram. 


\section{ROLES AND RESPONSIBILITIES}

\subsection{ENVIRONMENTAL RESTORATION ORGANIZATION}

The site environmental restoration programs collect tank construction data and are responsible for overseeing the data activities for transmitting data to the DOE, appropriate regulatory agencies, and to OREIS. Other responsibilities include compiling data into a data base; quality assuring data and metadata; transmitting data to OREIS as defined in this specification; and using valid values listings (e.g., codes, parameters, units of measure) as agreed upon by the team. Each site is responsible for data verification and standardization prior to transmitting data to OREIS.

\subsection{OREIS}

OREIS is the consolidated environmental data base that provides consistent and well documented environmental data and data products to support the planning, decision making, and reporting activities of DOE, DOE's M\&O contractor, DOE's prime contractors, and DOE subcontractors. OREIS will receive and process tank construction data from the sites as defined in this specification. OREIS responsibilities include:

- obtaining a data transmittal package from each site which indicates the location of the data transfer file and the individual transmitting the data (e.g., the site may have a directory on the OREIS machine where the data transfer file can be copied; the transmittal package tells OREIS the file is ready to process);

- processing the data received;

- conducting data base integrity checks;

- loading the data into OREIS;

- providing a processing summary for review by data generators (to obtain authorization to release the data to the public);

- providing the data and metadata to DOE, Environmental Protection Agency (EPA), and Tennessee Department of Environment and Conservation (TDEC);

- providing a user-friendly and integrated means of accessing the data contained in the OREIS data base;

- maintaining and validating the valid values listings for codes, parameters, units of measure, analysis methods, etc.;

- maintaining a data dictionary which defines all OREIS data base tables, field names, field definitions, field formats, field optionality, etc.;

- communicating changes to the lists of OREIS code values to users through the OREIS User Services activities; 
- providing a way for modifications to this specification and the tank construction data to be easily communicated and implemented using the latest revision of ER procedure ERWM/ER-P2703, Submitting, Reviewing, and Approving Changes to the Oak Ridge Environmental Information System (OREIS); and

- making every possible and reasonable effort to ensure that the tank construction data are not manipulated or misrepresented such that invalid conclusions may be drawn from the use of the data. 


\section{LOGICAL FILE LAYOUT AND BUSINESS RULES}

This section contains a logical representation of the subset of the OREIS model that pertains to the tank construction data. The entity names, entity definitions, field names, data types, field lengths, and field definitions are shown for each entity type. The requirement for each field is shown under the Req. (requirement) column. The categories are " $M$ " (mandatory), " $R$ " (recommended), and " $C$ " (conditional). Field names marked " $M$ " must be sent to OREIS. The data for " $R$ " fields, if it is available or can be obtained, should be transmitted to OREIS. The physical data base field name is in ("प") brackets.

Specifications for physically transmitting data to OREIS and associated submission rules are in Sect. 7.

\subsection{TANK CONSTRUCTION DATA} OREIS.

The following entity types contain fields associated with transferring tank construction data to

\subsubsection{PROJECT Entity Type}

A PROJECT is an environmental program responsible for collecting samples or taking measurements and creating regulatory reports. A PROJECT is defined by its site (or facility), sponsor, and project domain (either the geographic domain of the project within a site or its thematic domain).

\begin{tabular}{|c|c|c|c|c|}
\hline Field Name & Data Type & Length & Req. & Definition \\
\hline $\begin{array}{l}\text { Project Site } \\
\text { [PROJ_SITE] }\end{array}$ & VARCHAR2 & 10 & $\mathbf{M}$ & $\begin{array}{l}\text { Coded value that represents } \\
\text { the site initiating the work } \\
\text { (e.g., X-10, Y-12, K-25, } \\
\text { ORR, PAD, PORTS, } \\
\text { OFFSITE). See CODE table } \\
\text { where CODE_TYPE = } \\
\text { PROJ_SITE for a list of valid } \\
\text { values and their descriptions. }\end{array}$ \\
\hline $\begin{array}{l}\text { Project Code } \\
\text { [PROJ_CODE] }\end{array}$ & VARCHAR2 & 30 & $\mathbf{M}$ & $\begin{array}{l}\text { Acronym assigned by the } \\
\text { project (e.g., 'FCAP' for } \\
\text { Filled Coal Ash Pond, } \\
\text { 'NPDES' for National } \\
\text { Pollutant Discharge } \\
\text { Elimination System, K-25 } \\
\text { Groundwater, Y-12 } \\
\text { Groundwater). }\end{array}$ \\
\hline
\end{tabular}


Field Name
Project Name
[PROJ_NAME]

Date Completed

[D_COMPLETED]

Date Initiated

[D_INITLATED]

Project Contact

[PROJ_CONTACT]

Project Description

[PROJ_DESCRIPTION]

Project Program

[PROJ_PROGRAM]

Sponsor

[SPONSOR]

VARCHAR2 $\quad 50$

VARCHAR2

60

[ADS_NAME]

ADS Number

[ADS_NUM]

Comments

[COMMENTS]

\section{DATE}

DATE

VARCHAR2 20

VARCHAR2 8

\section{Data Type Length Req. Definition}

VARCHAR2 $100 \quad M \quad$ Name of the project assigned by the project staff (e.g., National Pollutant Discharge Elimination System, Y-12 Groundwater).

C

Date the project was completed, if applicable.

R Date that the project was initiated.

R The person at the site responsible for reporting data to DOE, the State of Tennessee, or a regulatory agency (e.g., format $=$ JB SMITH).

VARCHAR2 $240 \quad \mathrm{R} \quad$ Description of the project, often taken from ORR Site Management Plan of the ER Program.

R

The environmental program, legislation, or DOE order that initiated the project (e.g., the Clean Water Act [CWA]).

R The organization responsible for data generation (e.g., Y-12 Environmental Management).

R Activity data sheet name.

$\begin{array}{llll}\text { VARCHAR2 } & 10 & R & \text { Activity data sheet number. }\end{array}$

VARCHAR2 $2000 \quad R \quad$ Comments about the project. 
Business Rules:

- If a PROJECT record already exists in OREIS, with the submission of tank construction data the PROJ_SITE, PROJ_CODE, and PROJ_NAME must be supplied at a minimum to help identify the PROJECT the tank construction data belongs to.

\subsubsection{STATION Entity Type}

The STATION table contains data about sampling points associated with one or more projects. Each point has a distinct station name/station type within a project.

\begin{tabular}{|c|c|c|c|c|}
\hline Field Name & Data Type & Length & Req. & Definition \\
\hline $\begin{array}{l}\text { Station Name } \\
\text { [STA_NAME] }\end{array}$ & VARCHAR2 & 15 & $\mathbf{M}$ & $\begin{array}{l}\text { Unique station name } \\
\text { assigned by the individual } \\
\text { projects (e.g., GW101). }\end{array}$ \\
\hline $\begin{array}{l}\text { Station Type } \\
\text { [STA_TYPE] }\end{array}$ & VARCHAR2 & 2 & M & $\begin{array}{l}\text { Coded value that represents } \\
\text { the type of station (e.g., } \\
\text { seep, spring, well). See } \\
\text { CODE table where } \\
\text { CODE_TYPE = } \\
\text { STA_TYPE for a list of } \\
\text { valid values and their } \\
\text { descriptions. }\end{array}$ \\
\hline $\begin{array}{l}\text { Station Status } \\
\text { [STA_STATUS] }\end{array}$ & VARCHAR2 & 2 & $\mathbf{R}$ & $\begin{array}{l}\text { Coded value that represents } \\
\text { the status of the station (e.g., } \\
\text { active, inactive, destroyed, } \\
\text { lost, plugged and } \\
\text { abandandoned). See CODE } \\
\text { table where CODE_TYPE = } \\
\text { STA_STATUS for a list of } \\
\text { valid values and their } \\
\text { descriptions. }\end{array}$ \\
\hline $\begin{array}{l}\text { Station Description } \\
\text { [STA_DESC] }\end{array}$ & VARCHAR2 & 200 & $\mathbf{R}$ & $\begin{array}{l}\text { Description of the specific } \\
\text { sampling or measuring } \\
\text { location. }\end{array}$ \\
\hline $\begin{array}{l}\text { Date Discontinued } \\
\text { [D_DISCONTINUED] }\end{array}$ & DATE & . & $\mathrm{C}$ & $\begin{array}{l}\text { Date the station was } \\
\text { discontinued or plugged and } \\
\text { abandoned in the field, if } \\
\text { applicable. }\end{array}$ \\
\hline $\begin{array}{l}\text { Date Established } \\
\text { [D_ESTABLISHED] }\end{array}$ & DATE & . & $\mathrm{C}$ & $\begin{array}{l}\text { Date the station was } \\
\text { established in the field. For a } \\
\text { hole, this is the date when } \\
\text { construction of the hole is } \\
\text { completed. }\end{array}$ \\
\hline
\end{tabular}




\begin{tabular}{|c|c|c|c|c|}
\hline Field Name & Data Type & Length & Req. & Definition \\
\hline $\begin{array}{l}\text { Associated Facility } \\
\text { Number } \\
\text { [ASSOC_FACILITY_ } \\
\text { NO] }\end{array}$ & VARCHAR2 & 8 & C & $\begin{array}{l}\text { Environmental Restoration } \\
\text { Program Facility or building } \\
\text { number associated with the } \\
\text { station. }\end{array}$ \\
\hline $\begin{array}{l}\text { Comments } \\
\text { [COMMENTS] }\end{array}$ & VARCHAR2 & 2000 & $\mathbf{R}$ & Comments about the station \\
\hline
\end{tabular}

Business Rule(s):

- The STA_NAME + STA_TYPE must be unique within a project.

- If a STATION record already exists in OREIS for a particular tank, at a minimum the STA_NAME and STA_TYPE must be supplied with the submission of tank construction data to help identify the STATION the tank construction data are associated with.

\subsubsection{LOCATION Entity Type}

The LOCATION table contains coordinate and other information describing a point on the ground. Most locations are points described by $\mathrm{x} y$ coordinates, but a location could be a line or a polygon where measuring events occur. In those cases, a single point, such as the estimated center point, is used.

\begin{tabular}{|c|c|c|c|c|}
\hline Field Name & Data Type & Length & Req. & Definition \\
\hline $\begin{array}{l}\text { Site } \\
\text { [SITE] }\end{array}$ & VARCHAR2 & 10 & $\mathbf{M}$ & $\begin{array}{l}\text { Coded value that } \\
\text { represents the site where } \\
\text { the coordinates are } \\
\text { located (e.g., X-10, Y-12, } \\
\text { K-25, ORR, PAD, } \\
\text { PORTS, OFFSITE). See } \\
\text { CODE table where } \\
\text { CODE_TYPE = SITE } \\
\text { for a list of valid values } \\
\text { and their descriptions. }\end{array}$ \\
\hline $\begin{array}{l}\text { Received X Coordinate } \\
\text { [RCVD_X] }\end{array}$ & NUMBER & . & $\mathbf{M}$ & $\begin{array}{l}\text { Received X-value of the } \\
\text { distance in feet or } \\
\text { decimal degrees, of a } \\
\text { sampling or measuring } \\
\text { location from the } \\
\text { reference location. }\end{array}$ \\
\hline
\end{tabular}




\begin{tabular}{|c|c|c|c|c|}
\hline Field Name & Data Type & Length & Req. & Definition \\
\hline $\begin{array}{l}\text { Received Y Coordinate } \\
\text { [RCVD_Y] }\end{array}$ & NUMBER & $\cdot$ & $\mathbf{M}$ & $\begin{array}{l}\text { Received Y-value of the } \\
\text { distance in feet or } \\
\text { decimal degrees, of a } \\
\text { sampling or measuring } \\
\text { location from the } \\
\text { reference location. }\end{array}$ \\
\hline $\begin{array}{l}\text { Received Coordinate } \\
\text { System } \\
\text { [RCVD_COORD_SYS] }\end{array}$ & VARCHAR2 & 10 & $\mathbf{M}$ & $\begin{array}{l}\text { Coded value that } \\
\text { represents the coordinate } \\
\text { system which defines } \\
\text { units used for RCVD_X } \\
\text { and RCVD_Y. See } \\
\text { CODE table where } \\
\text { CODE_TYPE = } \\
\text { RCVD_COORD_SYS } \\
\text { for a list of valid values } \\
\text { and their descriptions. }\end{array}$ \\
\hline $\begin{array}{l}\text { Date Location Established } \\
\text { [D_LOC_ESTABLISHED] }\end{array}$ & DATE & . & $\mathbf{R}$ & $\begin{array}{l}\text { The date the location was } \\
\text { surveyed. }\end{array}$ \\
\hline $\begin{array}{l}\text { Elevation Error } \\
\text { [ELV_ERROR] }\end{array}$ & NUMBER & . & $\mathbf{R}$ & $\begin{array}{l}\text { Elevation measurement } \\
\text { error in feet. }\end{array}$ \\
\hline $\begin{array}{l}\text { Elevation Method } \\
\text { [ELV_METHOD] }\end{array}$ & VARCHAR2 & 10 & $\mathrm{C}$ & $\begin{array}{l}\text { Coded value that } \\
\text { represents the elevation } \\
\text { measurement method. } \\
\text { See CODE table where } \\
\text { CODE_TYPE = } \\
\text { ELV METHOD for a } \\
\text { list of valid values and } \\
\text { their descriptions. }\end{array}$ \\
\hline $\begin{array}{l}\text { Ground Elevation } \\
\text { [GRND_ELV] }\end{array}$ & NUMBER & . & $\mathbf{R}$ & $\begin{array}{l}\text { Elevation of ground } \\
\text { surface (for groundwater, } \\
\text { soil, or sediment } \\
\text { sampling) at a sampling } \\
\text { or measuring location in } \\
\text { feet above mean sea level } \\
\text { (msl). }\end{array}$ \\
\hline $\begin{array}{l}\text { Location Description } \\
\text { [LOC_DESC] }\end{array}$ & VARCHAR2 & 200 & $\mathbf{R}$ & $\begin{array}{l}\text { The description of the } \\
\text { location of the station. }\end{array}$ \\
\hline $\begin{array}{l}\text { Solid Waste Management } \\
\text { Unit } \\
\text { [SWMU] }\end{array}$ & VARCHAR2 & 10 & $\mathrm{C}$ & $\begin{array}{l}\text { Acronym for Solid Waste } \\
\text { Management Unit, if } \\
\text { applicable. }\end{array}$ \\
\hline
\end{tabular}




\begin{tabular}{|c|c|c|c|c|}
\hline Field Name & Data Type & Length & Req. & Definition \\
\hline $\begin{array}{l}\text { Comments } \\
\text { [COMMENTS] }\end{array}$ & VARCHAR2 & 2000 & $\mathbf{R}$ & $\begin{array}{l}\text { Comments about the } \\
\text { location. }\end{array}$ \\
\hline
\end{tabular}

\subsubsection{STATION_EVENT Entity Type}

The STATION_EVENT table contains data about an event occurring at one station, during which SAMPLEs and any associated FLD_SMP_MEASurements are taken at a point in time. FIELD_MEASurements can also be taken during a STATION_EVENT which are not directly associated with a SAMPLE.

\begin{tabular}{|c|c|c|c|c|}
\hline Field Name & Data Type & Length & Req. & Definition \\
\hline $\begin{array}{l}\text { Date Start } \\
\text { [D_START] }\end{array}$ & DATE & . & $\mathbf{M}$ & $\begin{array}{l}\text { The date the sampling began } \\
\text { at the STATION. }\end{array}$ \\
\hline $\begin{array}{l}\text { Date End } \\
\text { [D_END] }\end{array}$ & DATE & - & $\mathbf{M}$ & $\begin{array}{l}\text { The date the sampling ended at } \\
\text { the STATION. }\end{array}$ \\
\hline $\begin{array}{l}\text { Event Name } \\
\text { [EVENT_NAME] }\end{array}$ & VARCHAR2 & 40 & $\mathbf{R}$ & $\begin{array}{l}\text { The EVENT_NAME indicates } \\
\text { the grouping of measurement } \\
\text { results designated by the } \\
\text { project. }\end{array}$ \\
\hline $\begin{array}{l}\text { Time End } \\
\text { [T_END] }\end{array}$ & VARCHAR2 & 4 & $\mathbf{R}$ & $\begin{array}{l}\text { The time the sampling ended } \\
\text { at the station. }\end{array}$ \\
\hline $\begin{array}{l}\text { Time Start } \\
{\left[T_{\text {_START }} \text { STA }\right.}\end{array}$ & VARCHAR2 & 4 & $\mathbf{R}$ & $\begin{array}{l}\text { The time the sampling started } \\
\text { at the station. }\end{array}$ \\
\hline $\begin{array}{l}\text { Comments } \\
\text { [COMMENTS] }\end{array}$ & VARCHAR2 & 2000 & $\mathbf{R}$ & $\begin{array}{l}\text { Comments about the station } \\
\text { event. }\end{array}$ \\
\hline
\end{tabular}

\section{Business Rules:}

- If a STATION_EVENT record already exists in OREIS, with the submission of tank construction data the D_START, D_END and/or EVENT_NAME must be supplied at a minimum to help identify the STATION_EVENT the tank construction data belongs to.

\subsubsection{STAT_ALIAS Entity Type}

An alternate name by which a given station is identified.

\begin{tabular}{|c|c|c|c|c|}
\hline Field Name & Data Type & Length & Req. & Definition \\
\hline $\begin{array}{l}\text { Alias Name } \\
\text { [ALIAS_NAME] }\end{array}$ & VARCHAR2 & 40 & $\mathbf{M}$ & $\begin{array}{l}\text { Alternative or additional } \\
\text { names used in records and } \\
\text { reports to refer to the station. }\end{array}$ \\
\hline
\end{tabular}




$\begin{array}{lllll}\text { Field Name } & \text { Data Type } & \text { Length } & \text { Req. } & \text { Definition } \\ \begin{array}{l}\text { Comments } \\ \text { [COMMENTS] }\end{array} & \text { VARCHAR2 } & 2000 & \mathrm{R} & \begin{array}{l}\text { Comments about the station } \\ \text { alias. }\end{array}\end{array}$

\subsubsection{PROJECT_STATION_EVENT Entity Type}

The PROJECT_STATION_EVENT table is an association of a STATION_EVENT which has data of interest to a specific PROJECT. Resolves the fact that data collected during a particular STATION_EVENT may be shared by multiple PROJECTs.

\begin{tabular}{|c|c|c|c|c|}
\hline Field Name & Data Type & Length & Req. & Definition \\
\hline $\begin{array}{l}\text { Station Group } \\
\text { [STA_GROUP] }\end{array}$ & VARCHAR2 & 30 & $\mathbf{R}$ & $\begin{array}{l}\text { The STA_GROUP indicates } \\
\text { the grouping of stations } \\
\text { designated by the } \\
\text { project_based sampling design } \\
\text { or other criteria (e.g., general } \\
\text { category of discharge). For } \\
\text { NPDES data, this field will } \\
\text { contain one of the following } \\
\text { outfall categories: } \\
\text { CATEGORY I, CATEGORY } \\
\text { II, CATEGORY III, and } \\
\text { CATEGORY IV. A category } \\
\text { is a grouping of out falls for } \\
\text { NPDES data. }\end{array}$ \\
\hline $\begin{array}{l}\text { Sample Group } \\
\text { [SMP_GROUP] }\end{array}$ & VARCHAR2 & 30 & $\mathbf{R}$ & $\begin{array}{l}\text { The SMP_GROUP indicates } \\
\text { the grouping of measurement } \\
\text { events designated by the } \\
\text { project-based sampling design } \\
\text { or other criteria, if available. }\end{array}$ \\
\hline
\end{tabular}

\section{Business Rules:}

- The STA_GROUP is used to indicate the grouping of tanks (e.g., GROUP1, GROUP2).

\subsubsection{TANK Entity Type}

A TANK is an environmental container as defined in the Federal Facility Agreement (FFA) for the Oak Ridge Reservation (ORR). A tank is assigned to one of four categories (A, B, C, D). A tank can be new or replacement tank system(s) with secondary containment; an existing tank system(s) with secondary containment; an existing tank system(s) without secondary containment; or an existing tank system(s) without secondary containment that are removed from service. 


\author{
Field Name \\ Federal Facility Agreement \\ Category \\ [FFA_CAT] \\ Level Detection \\ [LEVEL_DETECT]
}

Tank Construction Material

[TANK_CONSTR_MAT]

Cathode Protection

[CATH_PROT]

Tank Orientation

[TANK_ORIENT]

Outer Diameter Value

[OUTER_DIAM_VAL]

\section{Data Type Length Req. Definition}

$\begin{array}{llll}\text { VARCHAR2 } & 2 & M & \text { Coded value that represents }\end{array}$ the Federal Facility Agreement Category assigned to a tank. See CODE table where CODE_TYPE $=$ FFA_CAT for a list of valid values and their descriptions.

VARCHAR2 4

R Coded value that represents the type of device installed to measure tank levels. See CODE table where CODE_TYPE $=$ LEVEL_DETECT for a list of valid values and their descriptions.

VARCHAR2 3

M

Coded value that represents the physical material used to construct the tank shell and related components. See CODE table where CODE_TYPE $=$ TANK_CONSTR_MAT for a list of valid values and their descriptions.

$\begin{array}{lll}\text { VARCHAR2 } 2 & R\end{array}$

A logical field denoting if cathodic protection was implemented for the tank (e..g., $\mathrm{Y}=\mathrm{Yes}, \mathrm{N}=\mathrm{No}, \mathrm{NA}=\mathrm{Not}$ Available).

VARCHAR2 1

R Coded value that represents the orientation of the tank's major axis. See CODE table where CODE_TYPE = TANK_ORIENT for a list of valid values and their descriptions.

NUMBER

R Measurement of the outer diameter about the tank's major axis, in feet. 


\begin{tabular}{|c|c|c|c|c|}
\hline Field Name & Data Type & Length & Req. & Definition \\
\hline $\begin{array}{l}\text { Height Value } \\
\text { [HEIGHT_VAL] }\end{array}$ & NUMBER & & $\mathrm{C}$ & $\begin{array}{l}\text { Measurement of height about } \\
\text { the tank's major axis. The } \\
\text { height of the tank must be } \\
\text { supplied if the } \\
\text { TANK_ORIENT is vertical. }\end{array}$ \\
\hline $\begin{array}{l}\text { Length Value } \\
\text { [LENGTH_VAL] }\end{array}$ & NUMBER & & $\mathrm{C}$ & $\begin{array}{l}\text { Measurement of length about } \\
\text { the tank's major axis. The } \\
\text { length of the tank must be } \\
\text { supplied if the } \\
\text { TANK_ORIENT is } \\
\text { horizontal. }\end{array}$ \\
\hline $\begin{array}{l}\text { Capacity } \\
\text { [CAPACITY] }\end{array}$ & NUMBER & & $\mathbf{R}$ & Measurement of tank volume. \\
\hline $\begin{array}{l}\text { Capacity Unit } \\
\text { [CAP_UNIT] }\end{array}$ & VARCHAR2 & 10 & $\mathbf{R}$ & $\begin{array}{l}\text { Coded value that represents } \\
\text { the units of measure used to } \\
\text { report the parameter value. } \\
\text { See CODE table where } \\
\text { CODE_TYPE = CAP_UNITS } \\
\text { for a list of valid values and } \\
\text { their descriptions. }\end{array}$ \\
\hline $\begin{array}{l}\text { Burial Depth } \\
\text { [BURIAL_DEPTH] }\end{array}$ & NUMBER & & $\mathbf{R}$ & $\begin{array}{l}\text { Burial depth to top of tank, } \\
\text { relative to the ground surface. }\end{array}$ \\
\hline $\begin{array}{l}\text { Burial Depth Unit } \\
\text { [BURIAL_UNIT] }\end{array}$ & VARCHAR2 & 10 & $\mathbf{R}$ & $\begin{array}{l}\text { Coded value that represents } \\
\text { the units of measure used to } \\
\text { report the parameter value. } \\
\text { See CODE table where } \\
\text { CODE_TYPE = } \\
\text { BURIAL_UNITS for a list of } \\
\text { valid values and their } \\
\text { descriptions. }\end{array}$ \\
\hline $\begin{array}{l}\text { Shell Thickness } \\
\text { [SHELL_THICKNESS] }\end{array}$ & NUMBER & & $\mathbf{R}$ & $\begin{array}{l}\text { Measurement of tank wall } \\
\text { thickness about the major axis. }\end{array}$ \\
\hline $\begin{array}{l}\text { Shell Thickness Unit } \\
\text { [SHELL_UNIT] }\end{array}$ & VARCHAR2 & 10 & $\mathbf{R}$ & $\begin{array}{l}\text { Coded value that represents } \\
\text { the units of measure used to } \\
\text { report the parameter value. } \\
\text { See CODE table where } \\
\text { CODE_TYPE = } \\
\text { SHELL_UNITS for a list of } \\
\text { valid values and their } \\
\text { descriptions. }\end{array}$ \\
\hline
\end{tabular}




\begin{tabular}{|c|c|c|c|c|}
\hline Field Name & Data Type & Length & Req. & Definition \\
\hline $\begin{array}{l}\text { Head Thickness } \\
\text { [HEAD_THICKNESS] }\end{array}$ & NUMBER & & $\mathbf{R}$ & $\begin{array}{l}\text { Measurement of tank wall } \\
\text { thickness at ends or } \\
\text { top/bottom. }\end{array}$ \\
\hline $\begin{array}{l}\text { Head Thickness Unit } \\
\text { [HEAD_UNIT] }\end{array}$ & VARCHAR2 & 10 & $\mathbf{R}$ & $\begin{array}{l}\text { Coded value that represents } \\
\text { the units of measure used to } \\
\text { report the parameter value. } \\
\text { See CODE table where } \\
\text { CODE_TYPE = } \\
\text { HEAD_UNITS for a list of } \\
\text { valid values and their } \\
\text { descriptions. }\end{array}$ \\
\hline
\end{tabular}

\subsubsection{TANK_MEDIA_TYPE Entity Type}

The TANK_MEDIA_TYPE is the medium(s) from which a sample was collected in the tank.

\section{Field Name Data Type Length Req. Definition}

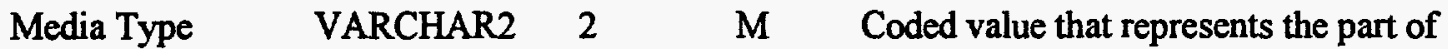
[MED_TYPE] the environment from which a sample is collected, or on which a field measurement or observation is made. See CODE table where CODE TYPE = MED_TYPE for a list of valid values and their descriptions.

\subsubsection{CONTAIN_SYS_TYPE Entity Type}

The CONTAIN_SYS_TYPE table relates to the structural integrity as defined by DOE for each tank system.

\begin{tabular}{|c|c|c|c|c|}
\hline Field Name & Data Type & Length & Req. & Definition \\
\hline $\begin{array}{l}\text { Containment System Type } \\
\text { [CONTAIN_SYS_TYPE] }\end{array}$ & VARCHAR2 & 4 & $\mathbf{M}$ & $\begin{array}{l}\text { Coded value that represents the } \\
\text { method of secondary } \\
\text { containment for a tank. See } \\
\text { CODE table where } \\
\text { CODE_TYPE = } \\
\text { CONTAIN_SYS_TYPE for a } \\
\text { list of valid values and their } \\
\text { descriptions. }\end{array}$ \\
\hline
\end{tabular}




\subsubsection{REFERENCE_SOURCE Entity Type}

A REFERENCE_SOURCE is a reference to any documentation containing detailed information about a specific location, or the effluent limitations and monitoring requirements under which stations are monitored (e.g., NPDES permit).

\begin{tabular}{|c|c|c|c|c|}
\hline Field Name & Data Type & Length & Req. & Definition \\
\hline $\begin{array}{l}\text { Comments } \\
\text { [COMMENTS] }\end{array}$ & VARCHAR2 & 2000 & $\mathbf{R}$ & $\begin{array}{l}\text { Comments about the } \\
\text { reference source. }\end{array}$ \\
\hline $\begin{array}{l}\text { Document Title } \\
\text { [DOC_TITLE] }\end{array}$ & VARCHAR2 & 2000 & $\mathbf{R}$ & $\begin{array}{l}\text { The official title of a } \\
\text { given publication/ } \\
\text { document/geophysical } \\
\text { log. }\end{array}$ \\
\hline $\begin{array}{l}\text { Publication Date } \\
\text { [D_PUBLICATION] }\end{array}$ & DATE & & $\mathrm{R}$ & $\begin{array}{l}\text { The day, month, and } \\
\text { year on which a given } \\
\text { reference source was } \\
\text { disseminated. }\end{array}$ \\
\hline $\begin{array}{l}\text { Reference Source Number } \\
\text { [REF_SRCE_NUM] }\end{array}$ & VARCHAR2 & 20 & M & $\begin{array}{l}\text { A number which } \\
\text { identifies a specific } \\
\text { reference source for a } \\
\text { given location, bore } \\
\text { hole/well, or the permit } \\
\text { number(s) under which } \\
\text { the station is } \\
\text { monitored. }\end{array}$ \\
\hline
\end{tabular}




\section{CHANGES TO OREIS DATA MODEL}

This section describes proposed changes made to the OREIS data model to support tank construction data.

Add the following entity types and corresponding definitions to the data model:

TANK

Sect. 3.1.7

TANK_MEDIA_TYPE Sect. 3.1.8

CONTAIN_SYS_TYPE Sect. 3.1.9

Add the field ASSOC_FACILITY_NO to the STATION table with the following definition.

Field Name

Associated Facility Number [ASSOC_FACILITY_NO]

\section{Data Type Length Req. Definition}

$\begin{array}{ll}\text { VARCHAR } 28 & 8\end{array}$

C Environmental Restoration Program Facility or building number associated with the station. 


\section{CHANGES TO OREIS CODE TABLES}

This section describes proposed changes made to the OREIS code tables to support tank construction data.

Add CODE_TYPE of FFA_CAT with the following codes.

$\begin{array}{lll}\begin{array}{l}\text { Code_Type } \\ \text { FFA_CAT }\end{array} & \text { Code } & \begin{array}{l}\text { Code_Description } \\ \text { A }\end{array} \\ \text { B } & \begin{array}{l}\text { Now or replacement tank system(s) with secondary } \\ \text { B }\end{array} & \begin{array}{l}\text { Existing tank system(s) with secondary } \\ \text { containment. }\end{array} \\ \text { C } & \begin{array}{l}\text { Existing tank system(s) without secondary } \\ \text { containment. }\end{array} \\ \text { D } & \begin{array}{l}\text { Existing tank system(s) without secondary } \\ \text { containment that are removed from service. }\end{array} \\ \text { UN } & \text { Unknown } \\ \text { ? } & \text { Other, defined in COMMENTS column }\end{array}$

Add CODE_TYPE of LEVEL_DETECT with the following codes.

$\begin{array}{lll}\text { Code_Type } & \text { Code } & \text { Code_Description } \\ \text { LEVEL_DETECT } & \text { CP } & \text { Conductivity Probe } \\ \text { FS } & \text { Float and Staff } \\ \text { PMG } & \text { Pmneumatic Gauge } \\ \text { UN } & \text { Unknown } \\ ? & \text { Other, defined in COMMENTS column }\end{array}$

Add CODE_TYPE of TANK_CONSTR_MAT with the following codes.

$\begin{array}{lll}\text { Code_Type } & \text { Code } & \text { Code_Description } \\ \text { TANK_CONSTR_MAT } & \text { CS } & \text { Carbon Steel } \\ & \text { GUN } & \text { Gunite } \\ & \text { MC } & \text { Metal Composite } \\ & \text { SLS } & \text { Stainless Steel }\end{array}$


UN Unknown

? Other, defined in COMMENTS column

Add CODE_TYPE of CONTAIN_SYS_TYPE with the following codes.

$\begin{array}{lll}\text { Code_Type } & \text { Code } & \text { Code_Description } \\ \text { CONTAIN_SYS_TYPE } & \text { CV } & \text { Concrete Vault } \\ \text { CPMS } & \text { Concrete Pit with Monitored Sump } \\ \text { CD } & \text { Concrete Dike } \\ \text { EPXV } & \text { Epoxy Lined Concrete Vault } \\ \text { RL } & \text { Rubber Lined } \\ \text { SLSV } & \text { Stainless Steel Lined Vault } \\ \text { UN } & \text { Unknown } \\ & ? & \text { Other, defined in COMMENTS column }\end{array}$

Add CODE_TYPE of TANK_ORIENT with the following codes.

$\begin{array}{lll}\text { Code_Type } & \text { Code } & \text { Code_Description } \\ \text { TANK_ORIENT } & \text { H } & \text { Horizontal } \\ & \text { V } & \text { Vertical }\end{array}$

Modify CODE_TYPE of MED_TYPE with the following codes.

$\begin{array}{lll}\text { Code_Type } & \text { Code } & \text { Code_Description } \\ \text { MED_TYPE } & \text { LT } & \text { Liquid from tank } \\ & \text { SN } & \text { Super natant }\end{array}$

Add CODE_TYPE of CAP_UNIT with the following codes.

$\begin{array}{lll}\text { Code_Type } & \text { Code } & \text { Code_Description } \\ \text { CAP_UNIT } & \text { gal } & \text { gallon }\end{array}$


18

Add CODE_TYPE of BURIAL_UNIT with the following codes.

Code_Type

BURIAL_UNIT
Code

$\mathrm{ft}$

in
Code_Description

foot

inch

Add CODE_TYPE of SHELL_UNITS with the following codes.

Code_Type

SHELL_UNIT
Code

in
Code_Description

inch

Add CODE_TYPE of HEAD_UNIT with the following codes.

Code_Type

HEAD_UNIT
Code

in
Code_Description

inch 


\section{VALID VALUES FOR OREIS CODE_TYPES}

The following list contains proposed valid values for those CODE_TYPES that pertain specifically to tank construction data. Refer to the latest revision of the Data Dictionary for the Oak Ridge Environmental Information System, ES/ER/TM-1 16, for the most current and complete listings of valid values for codes, parameters, and methods.

\begin{tabular}{|c|c|c|}
\hline Code_type & Code & Code_description \\
\hline \multirow[t]{5}{*}{ ELV_METHOD } & $?$ & $\begin{array}{l}\text { Other, defined in } \\
\text { COMMENTS column }\end{array}$ \\
\hline & $\mathrm{ECM}$ & Estimated from Contour Map \\
\hline & GPS & Global Positioning System \\
\hline & SURVEY & Survey Method \\
\hline & UNKNOWN & Unknown \\
\hline \multirow[t]{7}{*}{ PROJ_SITE } & $\mathrm{K}-25$ & K-25 Site \\
\hline & OFFSITE & Offsite \\
\hline & ORR & Oak Ridge Reservation \\
\hline & PAD & Paducah \\
\hline & PORTS & Portsmouth \\
\hline & $X-10$ & $\begin{array}{l}\text { Oak Ridge National } \\
\text { Laboratory }\end{array}$ \\
\hline & $Y-12$ & Y-12 Plant \\
\hline \multirow[t]{9}{*}{ RCVD_COORD_SYS } & $?$ & $\begin{array}{l}\text { Other, defined in } \\
\text { COMMENTS column }\end{array}$ \\
\hline & ADMIN & Administrative Grid \\
\hline & $\mathrm{K}-25$ & $\mathrm{~K}-25$ Grid \\
\hline & LATLON & Latitude/Longitude \\
\hline & ORNL & ORNL Grid \\
\hline & PAD & Paducah Grid \\
\hline & PORTS & Portsmouth Grid \\
\hline & STATE & State Plane \\
\hline & UNKN & Unknown \\
\hline
\end{tabular}




\begin{tabular}{|c|c|c|}
\hline \multirow[t]{2}{*}{ Code_type } & Code & Code_description \\
\hline & $\mathrm{Y}-12$ & Y-12 Grid \\
\hline \multirow{7}{*}{ SITE } & $\mathrm{K}-25$ & K-25 Site \\
\hline & OFFSITE & Offsite \\
\hline & ORR & Oak Ridge Reservation \\
\hline & PAD & Paducah \\
\hline & PORTS & Portsmouth \\
\hline & $X-10$ & $\begin{array}{l}\text { Oak Ridge National } \\
\text { Laboratory }\end{array}$ \\
\hline & $\mathrm{Y}-12$ & Y-12 Plant \\
\hline \multirow[t]{7}{*}{ STA_STATUS } & $?$ & $\begin{array}{l}\text { Other, defined in } \\
\text { COMMENTS column }\end{array}$ \\
\hline & $\mathrm{A}$ & Active station \\
\hline & $\mathrm{D}$ & Destroyed \\
\hline & I & Inactive station \\
\hline & $\mathbf{L}$ & Lost \\
\hline & PA & Plugged and Abandoned \\
\hline & UN & Unknown \\
\hline \multirow[t]{10}{*}{ STA_TYPE } & $\mathrm{AA}$ & Ambient Air \\
\hline & $\mathrm{BH}$ & Bore Hole \\
\hline & $\mathrm{BR}$ & Barrel \\
\hline & $\mathrm{CB}$ & Catch Basin \\
\hline & $\mathrm{CH}$ & Channel/Ditch \\
\hline & $\mathrm{CP}$ & $\begin{array}{l}\text { Composite From Several } \\
\text { Locations }\end{array}$ \\
\hline & $\mathrm{CT}$ & Cooling Tower \\
\hline & DK & Dike \\
\hline & FB & Fixed Location Building \\
\hline & FD & French Drain \\
\hline
\end{tabular}


Code_type

Code

FL

FR

FW

HP

LH

LK

$\mathrm{MH}$

NA

NF

OC

PP

RA

RE

RV

SE

SL

SP

SS

SU

SW

TF

TK

TP

WL

WP

WR

WW
Code_description

Flume

Fixed Location Receptacle

Faucet/Tap

Holding Pond/Lagoon

Leachate From Landfill

Lake/Pond

Manhole Cover

Not Available

Non-Fixed Location

Receptacle

Outcrop

Pipe

RAD Emissions

Reservoir

River/Stream

Seep

Surface Location

Spring

Surface Survey

Sump

Storm Water

Treatment Facility

Tank

Test Pit

Well (e.g., core hole, open hole, piezometer)

Well Point

Weir

Waste Water 


\section{DATA TRANSFER SPECIFICATIONS}

Data can be transferred to OREIS using SAS ${ }^{1}, \mathrm{DBF}$, Oracle ${ }^{2}$ Export files, or ASCII comma delimited files. These data base export file formats are specified in the latest revision of the ER procedure ERWM/ER-P2701, Transmitting Data in Ready-To-Load (RTL) Format to the Oak Ridge Environmental Information System (OREIS). Data that are transmitted to OREIS will be evaluated by OREIS staff to ensure that the transmitted data are consistent, complete, qualified, and documented. $^{3}$

\section{General Submission Rules:}

- Refer to procedure the latest revision of ERWM/ER-P2701, Transmitting Data in Ready-ToLoad (RTL) Format to the Oak Ridge Environmental Information System (OREIS), and to the training course for more details concerning submission rules.

- All mandatory fields must be populated with data, and all coded fields must use the OREIS codes, else the entire data transfer file will be returned to the site for correction and resubmission.

- STA_NAME and STA_TYPE must be unique within a project.

- Time must be 4 characters (e.g., 0700). All time is 24 hour local time zone.

- Coded fields must match OREIS codes exactly.

- The first eight characters of the field name must match OREIS field names exactly.

- The order of the fields does not matter if using SAS and DBF files. If using Oracle export files or ASCII comma delimited files the order must be specified.

- The number of records transmitted must be supplied on the data transmittal form.

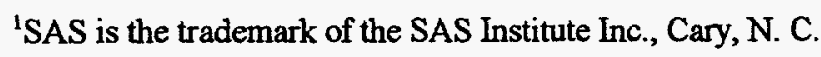

${ }^{2}$ Oracle is the trademark of the Oracle Corporation.

${ }^{3}$ Reference herein to any specific commercial product, process, or service by trade name, trademark, manufacturer, or otherwise, does not necessarily constitute or imply its endorsement, recommendation, or favoring by the United States Government or any agency thereof. 


\section{OREIS DATA INTEGRITY CHECKS}

Data that are transmitted to OREIS will be evaluated by OREIS staff to ensure that the transmitted data are consistent, complete, qualified and documented. The data base integrity checking process will confirm that (1) the number of records received matches the number of records transmitted, (2) the locations are valid, and (3) all coded fields sent to OREIS contain valid OREIS codes. OREIS will provide summary statistics to the users to verify what was loaded.

Reviews for data consistency and completeness may include (1) range checks, elementary statistics, or scatter plots of numeric and date fields to check for missing data, reasonable values, and outliers; (2) frequency tabulations and sorted lists of units, qualifiers, codes, and other selected character fields to check for missing data, miscoded data, and inconsistencies; (3) comparison of new and existing data to check for errors and wrong units of measure; (4) maps of station locations to verify coordinates; (5) checks to confirm that related records can be linked, (i.e., that laboratory measurement results match with records that define the field sampling date and the coordinates of the sampling location); and (6) other checks based on the data (e.g., check for samples from discontinued stations). 


\section{REQUESTING CHANGES TO TANK CONSTRUCTION DATA IN OREIS}

A request for a change to tank construction data stored in OREIS will be handled according to the latest revision of ER procedure, ERWM/ER-P2703, Submitting, Reviewing, and Approving Changes to the Oak Ridge Environmental Information System (OREIS). 


\section{CONFIGURATION CONTROL}

Configuration control of this technical specification will be handled according to the latest revision of the ER procedure, ERWM/ER-P2703, Submitting, Reviewing, and Approving Changes to the Oak Ridge Environmental Information System (OREIS). Users should request changes to this specification as stated in the above procedure. The change request will be documented, reviewed, and approved by all tank construction program groups and the OREIS staff. 


\section{REFERENCES}

EPA (Environmental Protection Agency), TDEC (Tennessee Department of Environment and Conservation -formerly TDHE: Tennessee Department of Health Environment), and DOE (U.S. Department of Energy), 1992. Federal Facility Agreement for the Oak Ridge Reservation, DOE/OR-104, U.S. Environmental Protection Agency Region IV, U.S. Department of Energy, Tennessee Department of Environment and Conservation, Atlanta, Georgia.

OREIS (Oak Ridge Environmental Information System), 1996. Data Dictionary for the Oak Ridge Environmental Information System (OREIS), ES/ER/TM-116/R1, Environmental Restoration Division, Lockheed Martin Energy Systems, Inc., Oak Ridge, Tennessee.

OREIS (Oak Ridge Environmental Information System), 1995. Submitting, Reviewing, and Approving Changes to the Oak Ridge Environmental Information System (OREIS), ERWM/ER-P2703, Rev. 1, Environmental Restoration Division Procedure, Lockheed Martin Energy Systems, Inc., Oak Ridge, Tennessee.

OREIS (Oak Ridge Environmental Information System), 1996. Transmitting Data in Ready-To-Load (RTL) Format to the Oak Ridge Environmental Information System (OREIS), ERWM/ER-P2701, Rev. 3, Environmental Restoration Division Procedure, Lockheed Martin Energy Systems, Inc., Oak Ridge, Tennessee.

TDEC (Tennessee Department of Environment and Conservation -formerly TDHE: Tennessee Department of Health Environment), and DOE (U. S. Department of Energy), 1991. Tennessee Oversight Agreement between the United States Department of Energy and the State of Tennessee, May 13, 1991. 
Appendix

OREIS ENTITY RELATIONSHIP DIAGRAM 
.

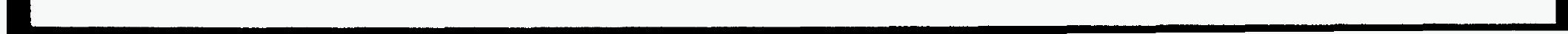

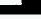




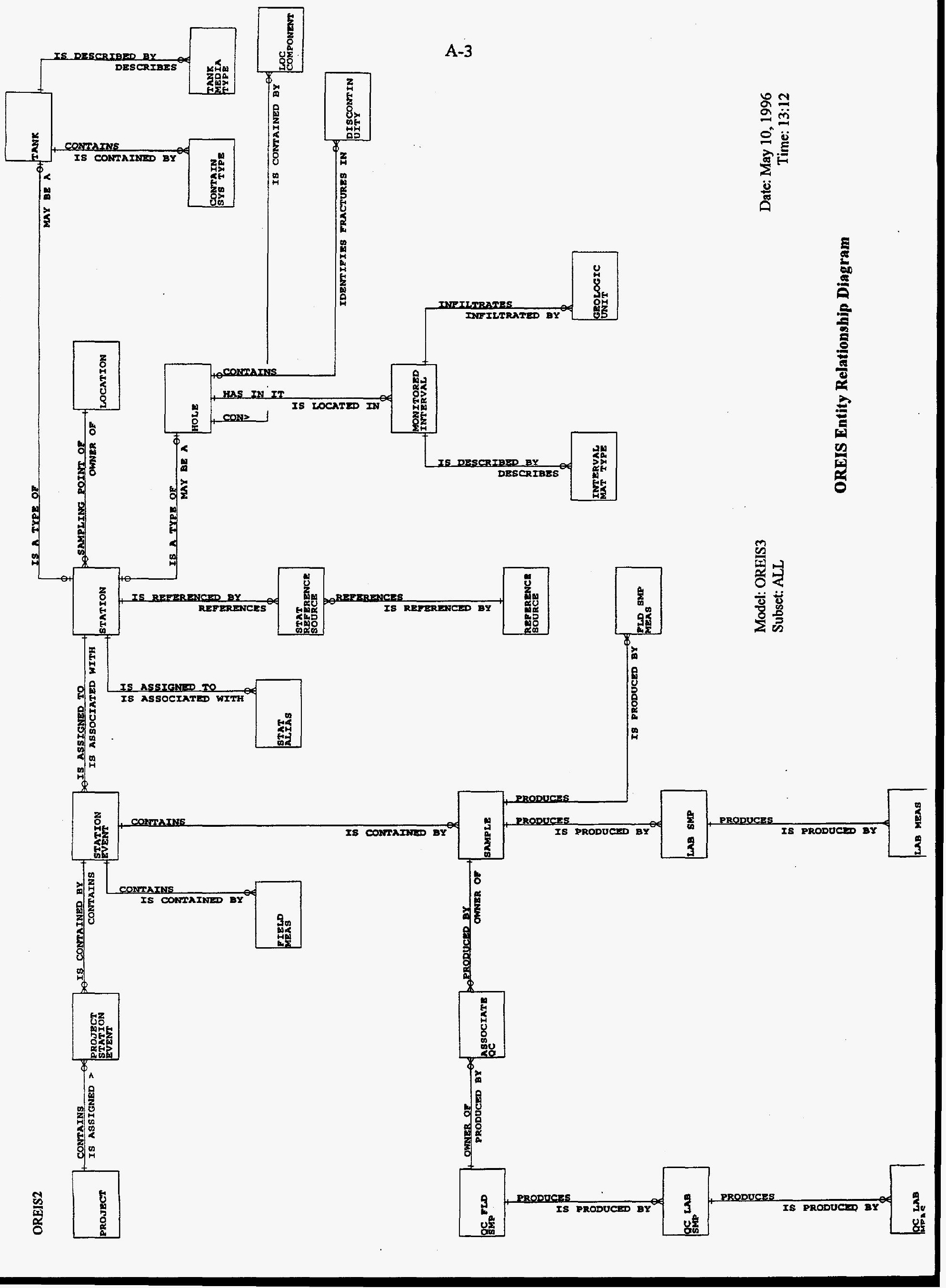




\section{DISTRIBUTION}

1. L. V. Asplund

2. B. W. Henderson

3. D. D. Herr

4. T. L. James

5. D. M. Matteo

6-11. M. P. North

12. P. T. Owen

13-15. A. S. Quist

16. A. M. Stanley

17. J. K. Thomas

18. B. A. Watts

19. D. C. White

20-21. M. L. Whitehead

22. B. C. Zygmunt

23. Central Research Library

24-25. ER Document Management Center-RC 